\title{
Accounting
}

\section{Supervision mechanism and quality of the internal control system disclosure}

\author{
Weli Weli $^{a^{*}}$, Julianti Sjarief ${ }^{\text {a }}$ and Synthia Madyakusumawatia
}

\begin{tabular}{|c|c|}
\hline C H R O N I C L E & A B S T RACT \\
\hline $\begin{array}{l}\text { Article history: } \\
\text { Received July } 22020 \\
\text { Received in revised format July } \\
262020 \\
\text { Accepted July } 292020 \\
\text { Available online } \\
\text { August } 42020 \\
\text { Keywords: } \\
\text { Internal control } \\
\text { Corporate governance } \\
\text { Board characteristics } \\
\text { Disclosure quality }\end{array}$ & $\begin{array}{l}\text { This study analyzes the effect of supervision activities on the quality of the internal control system. It ascertains } \\
\text { how the board of commissioners direct the company in presenting information as required by the stakeholders. The } \\
\text { presentation of adequate information on internal control is a part of good corporate governance. The study was } \\
\text { conducted on a public company in Indonesia, and data of } 119 \text { companies were collected using content analysis. The } \\
\text { items used in measuring the extent of disclosure were developed based on the } 2013 \text { COSO framework and directions } \\
\text { in the circular letter of number } 30 \text { /SEOJK.04/2016. A regression test with the IBM SPSS } 21 \text { program was used to } \\
\text { perform the data analysis. The analysis results showed empirical support for some characteristics of the board of } \\
\text { commissioners, such as the size, accounting and financial literacy, and the number of meeting in a year on the } \\
\text { quality of internal control system disclosure. This study provided a theoretical contribution by using supervision } \\
\text { mechanisms to overcome asymmetric information. Practical contributions are also expected to be conveyed to the } \\
\text { financial service authority regarding the independence proportion and gender diversity, that have not been generally } \\
\text { performed. The value of this research is an instrument that measures the quality of the disclosure adjusting } \\
\text { conditions in Indonesia. Design of measurement items based on rules is issued by the Financial Services Authority } \\
\text { for public companies. }\end{array}$ \\
\hline
\end{tabular}

C 2020 by the authors; licensee Growing Science, Canada

\section{Introduction}

The internal control system plays an important role on the quality of financial statement as a part of good corporate governance reported to the public (McNally, 2013). It has become a special concern when the Enron Company case involving one of the big five public accounting firms became known to the public. In 2002, SOX was created, and its section 404 regarded public company compliance on the framework of the internal control system. This system was previously made in 1992 by the Committee of Sponsoring Organizations of the Tread way Commission (COSO). Consequently, it experienced a change in 2013 called the COSO 2013, which is an improvement from the previously published framework, by making changes in 3 major areas, such as: 1) There is a codification of the principles and attributes to ease the development of internal control systems, simplified into seventeen principles. 2) Expansion of reporting objectives including financial and non-financial reporting, and also internal and external reporting. 3) The increased focus on operating objectives and compliance are based on user input.

Based on the COSO 2013 framework, the implementation of an internal control system will assist companies in mitigating the various risks faced by organizations. However, it was developed based on an effort to improve the performance of public companies and their management through effective risk management and fraud prevention. Therefore, it is important for public companies to follow the components available to achieve organizational goals.

* Corresponding author.

E-mail address: weli.imbiri@atmajaya.ac.id (W. Weli) 
The primary focus of the new COSO 2013 framework implies that the implementation of an effective internal control system by the organization will have an impact on the presentation of quality financial information. An effective system ensures business operations are performed with the right mechanism. However, it is in line with the agency theory that there is a conflict in companies that are managed by non-owners. Managers have a tendency to be opportunistic to fulfil their interests, thus there is information asymmetry which certainly will harm the principal. Furthermore, the quality of financial reporting by management becomes questionable by decision makers. One phenomenon that often occurs is that management will use discretionary accounts to transfer funds between two accounts. Although, considering the use of discretionary accruals, the quality of the financial statement will be greatly affected. The higher the discretion the lesser the quality of the report, and vice versa. A good report describes the performance of the company, and reflects the quality of its earning (Dechow et al., 2010). Furthermore, it can also reflect good operating cash flow (Dechow et al., 2010). Therefore, earning management activities will have an impact on the presentation of misleading company performance for stakeholders. For the organization's internal control system to run on target, another mechanism is needed to control management behaviour through monitoring (Agyei-Mensah, 2016; Ahmad et al., 2015). Although previous studies have shown that there are many determinants for the quality of its disclosure (Chalmers et al., 2019). Therefore, this study will specifically analyse from the concept of agency theory about supervision activities. Effective monitoring will limit the activities that deviate from the agent, and in the framework of good corporate governance, the supervision mechanism can be performed by the board of commissioners. This argument is in accordance with (Michelon et al., 2015) which states that the characteristics of the board of commissioners are seen from the proportion of independent activities. An effective supervision mechanism will guarantee that business operations are performed by the right procedures.

Previous findings show that there is an increase in the quality of financial reporting along with the improvement of company's internal control system (Ashbaugh-Skaife et al., 2008). It will produce a reliable financial statement, when all company personnel have followed the principles of internal control as their work guidelines. Additionally, it provides certainty for the achievement of the company's internal control system, which can improve the reliability of financial statements, thereby reducing the risk of material misstatement and fraud. Therefore, this research analyses the effect of supervision activities of the internal control system and how the characteristics of the board of commissioners are able to direct the company.

\section{Literature review and hypothesis formulation}

The agency theory is the basis of thinking for research related to information disclosure, the framework of this theory explains that companies will try to reduce agency costs through independent supervision mechanisms such as the board of commissioners (Agyei-Mensah, 2016), it is also needed for effective implementation of internal control system to secure company assets for the business situation that separates owners and managers. Based on the principle of Agency theory, there are differences in interests between the two parties, thus there needs to be a supervision mechanism. The framework can help in managing the business according to the rules of all stakeholders. Adequate information about its implementation needs to be conveyed properly to the stakeholders. However, policies regarding the disclosure of information have not been regulated in detail. Regulation of financial services, for example circular number 30 / SEOJK.04/2016, only regulate the form and content of public companies, the contents of which only indicate an explanation of financial and operational control, compliance with other laws and regulations, and a review of the effectiveness of the internal control system. Some issues have not been specifically regulated for non-banking companies. Therefore, it can be understood when they have not implemented standard internal control systems, with various levels of disclosure (Sjarief \& Weli, 2016; Weli \& Sjarief, 2017, 2018). Furthermore, results of previous studies concluded that the company only responded to the extent set by the Financial Services Authority (OJK), which is related to the internal control system and risk management in general. Although, most have used the COSO framework as a guide in the company.

In addition, another research was also performed by (Pangaribuan et al., 2019). They examine the practice of disclosure in the banking industry and concluded that only 36 percent of banks make full disclosure and there are still 5 percent of companies that have a low score of internal control. This result is lower than the previous practices performed in the non-banking industry (Sjarief \& Weli, 2016; Weli \& Sjarief, 2017, 2018). However, the difference in results may be due to indexing scores for the used disclosure items, thus the final scores obtained are also different. Therefore, it is important to re-examine the practices with 2013 COSO framework adjusted to the recommendations by the OJK.

In consequence, studies related to the quality of internal control systems are performed differently compared to countries that have implemented the Sarbanes-Oxley Act (SOX). In line with the existing policies, the quality of internal control is not measured using a management report on their weaknesses, since SOX has not been provided. However, it can only be accessed on annual reports which are published to the public, based on OJK recommendations. Furthermore, the measurement results can be used as a guide in assessing the quality of internal control system disclosures. 
Considering there are no standards regulating the information in annual reports, it is understood that there will be wide differences in disclosure among companies. The company will make it in accordance with their objectives and policies. One factor affecting the extent of information disclosure is the mechanism of corporate governance. In this study, the used mechanism is limited to the characteristics of the board of commissioners, considered to undergo the supervision function on the company's operations performed by the government.

\subsection{Characteristics of the board of commissioners and extent of disclosure}

In accordance with Financial Services Authority Regulation Number 33 /POJK.04/2014, the Board of Commissioners has a general supervision role and provides advice to the Directors. Previous studies (Agyei-Mensah, 2016; Ahmad et al., 2015; Haji \& Ghazali, 2013) showed their effectiveness can be identified by several characteristics such as board size, independence, gender diversity, accounting and financial expertise, frequency of meetings, and independence of the president commissioner.

In the same degree with the regulation of financial services authority Number $33 /$ POJK.04/2014, the company's board of commissioners is at least 2 people, 1 of which needs to be independent. Meanwhile, when the number of members is more than 2 , independent commissioners will at least be $30 \%$ of the total. Their number gives an impact on the strength of supervision activities on the work of management in financial reporting. Previous studies showed that the greater the number of members, the higher their capabilities in conducting supervision and control (Allegrini \& Greco, 2013). This is also in line with the concept of agency theory which emphasizes on their role in reducing asymmetric information (Agyei-Mensah, 2016). Their increased capabilities will affect the level of information transparency by management. Therefore, the amount and quality of delivered information will be increased. Furthermore, the independence of the board of commissioners is also an important factor in the quality of supervision and control, a higher proportion will direct more independent decisions. Therefore, it is able to reduce the opportunistic behavior of management, by increasing the quality of information presented to the public (Ahmad et al., 2015). This can happen when the chairman is from an independent circle. Other research (Agyei-Mensah, 2016), showed their size and independence can significantly influence the extent of the internal control system disclosure. These results provide empirical support that the characteristics of the board of commissioners are able to assist companies in improving the quality of information disclosure which is more transparent, due to effective supervision and control. However, it was concluded (AgyeiMensah, 2016) from previous literature studies that there were different results for this mechanism. Similarly, research conducted in four European countries (London, Paris, Frankfurt and Milan) by Michelon et al. (2015) showed a negative relationship between disclosure of internal control and the size of the supervisory board, where companies with strong supervision tend to less disclose internal control information than the ones with weak board. Meanwhile, Liao et al., (2015) obtained different results that the independence of commissioners influences the tendency of information disclosure.

A further characteristic of the board is their expertise in accounting and finance. Their financial mastery is believed to influence the quality of financial statement presentation. The financial literacy they possess will minimize earnings management routines measured by the accrual variable (Ahmad et al., 2015). The study results by Felo (2011) showed an independent board of commissioners with financial literacy will increase the level of information transparency. Having them as supervisors in the presentation of reports causes an adequate understanding of capital market rules and thus will support the application of internal controls and direct the presentation of more relevant information (Li et al., 2012). Furthermore, the knowledge about finance will affect the company's policies in supervising disclosure accurately (Adams \& Ferreira, 2008). The study results (Ahmad et al., 2015) confirm that their accounting and financial expertise influence the disclosure of internal control system.

Another issue related to the characteristics of the board of commissioners is gender diversity. It becomes an issue in the practice of good corporate governance, where in modern management, companies need to provide equal opportunities for both men and women (Liao et al., 2015). Specifically, (Chen et al., 2016) showed gender diversity would affect the mitigation activities of internal control weaknesses, and also affect the size of the board. Previous studies showed how it plays a role in the decision making process and supervision activities (Adams \& Ferreira, 2008). The greater composition of the female boards is believed to improve the quality of supervision because women are considered to have higher ethical and moral considerations (Huang et al., 2011). However, Adams \& Ferreira (2008) did not find the effect of gender diversity on company's performance, and they concluded that it will have an optimal role, when its effect is complex in companies with weak governance conditions. Conversely, for those with strong corporate governance, a broad size of will result in excessive supervision activities. Other results showed that the proportion of the number of female boards is highly correlated with the extent of information disclosure (Ben-Amar et al., 2017; Liao et al., 2015; Manita et al., 2018), and has a significant effect on all measurements (Ahmed et al., 2017). It was also revealed that the proportion of female boards made supervision activities more active, thus it would reduce the opportunistic behavior of managers and then increase wider disclosure of information (Ahmed et al., 2017).

The next characteristic of the board of commissioners can be seen from their activities in carrying out control and supervision through meetings conducted with managers or among members of the board. The frequency, as required by OJK Regulation Number 33 / PJOK.04 / 2014 article 31, is at least once every two months. The more the meetings, the higher effectiveness of 
the supervision function on the management, thus the information presented can be more extensive. The results of previous studies (Allegrini \& Greco, 2013; Barros et al., 2013) showed a positive relationship between the frequency of meetings with the extent of information disclosure to the company. It facilitates effective communication activities related to information that the board of commissioners needs to know. The intensity of communication between the two parties enables the management to disclose better information under pressure.

From the stated facts, there is an influence between the various characteristics of the board of commissioners on the extent of disclosure. Therefore, the research model and hypothesis are formulated as follows:

$\mathrm{H}_{1}$ : There is a positive influence between the size of the Board of Commissioners on the extent of disclosure of the company's internal control system.

$\mathrm{H}_{2}$ : There is a positive influence between the Independence of the Board of Commissioners on the extent of disclosure of the company's internal control system.

$\mathrm{H}_{3}$ : There is a positive influence between the independence of the President Commissioner on the extent of disclosure of the company's internal control system.

$\mathrm{H}_{4}$ : There is a positive influence between the Accounting Expertise of the Board of Commissioners on the extent of disclosure of the company's internal control system.

$\mathrm{H}_{5}$ : There is a positive influence between the Gender Diversity of the Board of Commissioners on the extent of disclosure of the company's internal control system.

$\mathrm{H}_{6}$ : There is a positive influence between the number of Board of Commissioners meetings on the extent of disclosure of the company's internal control system.

\subsection{Control variable}

This study specifically observes the role of the board of commissioner characteristic on the extent of disclosure. However, several variables will be used to control other factors that will influence its relationship. Previous studies have anticipated various organizational characteristics in information disclosure to the public. This research will use an approach of previous studies (Ahmed et al., 2017; Allegrini \& Greco, 2013; Barros et al., 2013; Manita et al., 2018), such as company size and measured leverage variables. Both of these are representative of the company's internal characteristics. The size of the company in the previous study provided evidence of its significant influence on disclosure, the greater the size in terms of its resources, the broader it tends to disclose information (Allegrini \& Greco, 2013; Barros et al., 2013; Ben-Amar et al., 2017; Manita et al., 2018). Another internal characteristic is leverage. Companies with high levels tend to reduce monitoring costs, thus making wider disclosures (Allegrini \& Greco, 2013). The results of the study (Ben-Amar et al., 2017), in contrast to a previous one, showed company size has a positive influence on the extent of disclosure and a negative influence on leverage (Ahmed et al., 2017).

\section{Research Methods and Instruments}

As a result of different Internal control for each type of industry, this study is limited to only one (Chalmers et al., 2019). The object is the annual report of public companies for trade industry groups based on grouping conducted (https://www.idx.co.id/media/7717/fb2019-halaman.pdf). In line with the aims of this study, sampling will be performed using the Slovin formula, which is:

$$
n=\frac{N}{1+N e^{2}}
$$

where $n$ is the desired number of samples, $N$ is the population number and $e$ is the $5 \%$ error rate. Calculation results of at least 114 samples can be obtained.

The study was conducted in Jakarta, and the data was collected using the content analysis of financial statements published on www.idx.co.id of 2018, and they contain items that reflect the application of the internal control system as explained in the measurement section of the following research variables.

\subsection{Operationalization of variables}

ICD (Internal Control Disclosures) is the dependent variable, measured using items required in the COSO 2013 framework and adjusted to circular letter number 30 /SEOJK.04/2016, which described the financial and operational controls in compliance with other laws and regulations., The items used to measure the extent of disclosure are shown in Table 1 as follows: 
Table 1

$\underline{\text { Statement items related to internal control systems }}$

\begin{tabular}{|c|c|}
\hline Code & Information Items \\
\hline GD & General description about the Internal Control Systems (IC) of Public Company (PC) \\
\hline GD1 & Definition and Objectives of IC \\
\hline GD2 & Statement of management responsibility in the IC of PC \\
\hline GD3 & Statement of audit committee responsibility in IC \\
\hline GD4 & Statement of internal audit responsibility in IC \\
\hline GD5 & Statement of usage of Standards such as COSO, Turnbull Framework or others \\
\hline EM & Evaluation and Monitoring of IC \\
\hline EM1 & Statement that management has assessed the application of IC \\
\hline EM2 & Statement of conclusions on the evaluation results of the application of IC \\
\hline EM3 & Statement of level of compliance with the reference standard of IC \\
\hline EM4 & Statement that management has discussed the specific elements of the IC of PC \\
\hline EM5 & Statement about regular assessment implementation of IC PC \\
\hline EM6 & Statement about the IC PC's assessment by internal audit \\
\hline EM7 & Management Code of Conduct \\
\hline $\mathrm{RP}$ & Reporting on Activities of IC \\
\hline RP1 & Statement of the limitations of IC PC \\
\hline RP2 & Statement of the findings of violations of IC PC \\
\hline RP3 & Statement that the handling of findings of violations or weaknesses of IC PC has been carried out \\
\hline $\mathrm{CE}$ & Control Environment \\
\hline CE1 & Description on the Meaning of the Control Environment Elements in PC \\
\hline CE2 & Explanation on the Application of the Control Environment Elements in PC \\
\hline RA & Risk Assessment \\
\hline RA1 & Description on the meaning of Risk Assessment Elements in PC \\
\hline RA2 & Explanation on the Application of Risk Assessment Elements in PC \\
\hline CA & Control Activities \\
\hline CA1 & Description on the meaning of Control Activities Elements in PC \\
\hline CA2 & Explanation on Application of Control Activities Elements in PC \\
\hline $\mathrm{IC}$ & Information and Communication \\
\hline IC1 & Description on the meaning of Information and Communication Elements in PC \\
\hline $\mathrm{IC} 2$ & Explanation on Application of Information and Communication Elements in PC \\
\hline $\mathrm{MN}$ & Monitoring \\
\hline MN1 & Description on the meaning of Monitoring Elements in PC \\
\hline MN2 & Explanation on Application of Monitoring Elements in PC \\
\hline
\end{tabular}

The extent of disclosure will be calculated by giving a value of 1 for the items disclosed and 0 for those not disclosed, then all values will be added up and divided by the total question items (25), resulting in an ICD score ranging from 0 to 1 . Furthermore, the independent variables are explained as follows:

BSIZE is the size of the board of commissioners, measured by their number.

PIND, is the proportion of independent boards of commissioners, measured by comparing their number to the total number of the members of the board of commissioners.

CIND, is the independence of the Independent President Commissioner, measured by a dichotomous variable, a value of 1 when the President Commissioner is from an independent party, 0 if not.

PEXP, is the number of commissioners with a background in financial accounting.

Gender diversity, is measured by the number of female board of commissioners.

MEET, is the number of meetings for one year, measured by the total number of meetings conducted by the board of commissioners during 2018. Then, the control variables variables are explained as follows:

FSize, is the size of the company, measured by the value of Total Assets.

$\mathrm{LEV}$, is the size of leverage, assessed from Debt to Total Asset Ratio.

\section{Results and Discussion}

In this study, data from 119 companies were collected and statistics analysis was performed using the IBMSPSS version 21 program. Meanwhile, the results were used for descriptive and hypothesis testing using the Regression Test. The analysis of the data collected on the practice of internal control system disclosure as presented in Table 2, shows a low level by companies with the trading industry, with an average score of $36 \%$. The most disclosed information by the company is the group of general description with an average score of $66 \%$, while the least disclosed information is the group reporting activities by the company with a value of $5 \%$. Furthermore, as presented in Table 2, it can be seen that companies with disclosure scores greater than 0.48 are only $16.81 \%$. Table 3 showed two companies that have the highest scores above $70 \%$ with ABMM and GLOB codes. Meanwhile, WICO, ZBRA, BAYU, CLAY, and PTSP were less than 10\%. 
Table 2

Internal Control Disclosure Score

\begin{tabular}{|c|c|c|}
\hline Code & Information Items & Mean \\
\hline GD & General description about the Internal Control Systems (IC) of Public Company (PC) & 0.66 \\
\hline GD1 & Definition and Objectives of IC & 0.65 \\
\hline GD2 & Statement of management responsibility in the IC of PC & 0.70 \\
\hline GD3 & Statement of audit committee responsibility in IC & 0.76 \\
\hline GD4 & Statement of internal audit responsibility in IC & 0.95 \\
\hline GD5 & Statement of usage of Standards such as COSO, Turnbull Framework or others & 0.24 \\
\hline EM & Evaluation and Monitoring of IC & 0.31 \\
\hline EM1 & Statement that management has assessed the application of IC & 0.23 \\
\hline EM2 & Statement of conclusions on the evaluation results of the application of IC & 0.46 \\
\hline EM3 & Statement of level of compliance with the reference standard of IC & 0.18 \\
\hline EM4 & Statement that management has discussed the specific elements of the IC of PC & 0.03 \\
\hline EM5 & Statement about regular assessment implementation of IC PC & 0.34 \\
\hline EM6 & Statement about the IC PC's assessment by internal audit & 0.18 \\
\hline EM7 & Management Code of Conduct & 0.74 \\
\hline $\mathrm{RP}$ & Reporting on Activities of IC & 0.05 \\
\hline RP1 & Statement of the limitations of IC PC & 0.03 \\
\hline RP2 & Statement of the findings of violations of IC PC & 0.06 \\
\hline RP3 & Statement that the handling of findings of violations or weaknesses of IC PC has been carried out & 0.05 \\
\hline $\mathrm{CE}$ & Control Environment & 0.27 \\
\hline CE1 & Description on the Meaning of the Control Environment Elements in PC & 0.02 \\
\hline CE2 & Explanation on the Application of the Control Environment Elements in PC & 0.52 \\
\hline RA & Risk Assessment & 0.37 \\
\hline RA1 & Description on the meaning of Risk Assessment Elements in PC & 0.03 \\
\hline RA2 & Explanation on the Application of Risk Assessment Elements in PC & 0.70 \\
\hline $\mathrm{CA}$ & Control Activities & 0.37 \\
\hline CA1 & Description on the meaning of Control Activities Elements in PC & 0.03 \\
\hline CA2 & Explanation on Application of Control Activities Elements in PC & 0.71 \\
\hline $\mathrm{IC}$ & Information and Communication & 0.36 \\
\hline IC1 & Description on the meaning of Information and Communication Elements in PC & 0.03 \\
\hline IC2 & Explanation on Application of Information and Communication Elements in PC & 0.69 \\
\hline $\mathrm{MN}$ & Monitoring & 0.37 \\
\hline MN1 & Description on the meaning of Monitoring Elements in PC & 0.03 \\
\hline MN2 & Explanation on Application of Monitoring Elements in PC & 0.71 \\
\hline & Total Score & 0.36 \\
\hline ICDS & \multicolumn{2}{|l|}{ Freq } \\
\hline $0-0,24$ & \multicolumn{2}{|l|}{30.25} \\
\hline $0,24-0,40$ & \multicolumn{2}{|l|}{18.49} \\
\hline $0,40-0,48$ & \multicolumn{2}{|l|}{34.45} \\
\hline$>0,48$ & \multicolumn{2}{|l|}{16.81} \\
\hline Total & 100.0 & \\
\hline
\end{tabular}

Source: Authors' calculations.

The results of the descriptive analysis showed the practice of information disclosure on internal control systems by public companies on the Indonesia Stock Exchange, especially the trading industry group, is still very low and there is only $1.7 \%$ with a score above 0.70 . It was concluded that many companies only presented information about the internal control system in general description only. Meanwhile, relevant information related to the implementation of supervision, evaluation, and reporting was not presented in full in their annual reports. Most companies do not explain the discussion about the management, the limitations and the violation of the internal control system. Furthermore, they also do not explain the description or understanding of each component of control, such as the control environment, risk assessment, control activities, information and communication, and monitoring. Based on these results, it was concluded that important information related to the implementation of internal control systems could not be conveyed to the public and it would be nice for the company to provide specific information related to matters regarding the implementation of evaluation and supervision by management for the course of business processes. This is very important for investors and creditors in the investment and funding decision-making process (Cheng et al., 2011 Rose, Norman, \& Rose, 2010; Lopez, Vandervelde, \& Wu, 2009; Kim \& Park, 2009; Waller Shelton \& Whittington, 2008; Holt \& DeZoort, 2009 Schneider \& Church, 2008; Kim, Song, \& Zhang, 2011; Aghazadeh, 2013).

Descriptive analysis results for the independent variables were summarized in Table 4. It showed that most companies have used the number of boards exceeding the standards set by the FSA, which is an average of 3 people, and a total of $58.8 \%$ have used 3-5 board of commissioners and 16.8\% have used than 5. However, the large number of them has not been matched by the number of independent boards of commissioners, because the proportion is still largely less than 0.5 . Similarly, $87.4 \%$ of companies do not have an independent president. Another characteristic, the background of financial accounting expertise, showed that only $9.2 \%$ of companies do not have a board of commissioners with a background in financial accounting expertise. 
W. Weli et al. /Accounting $6(2020)$

Most companies (63\%) have between 1-2 expertise in the field of accounting and 27.7\% have more than 3 members of the board of commissioners with a background in the profession. Furthermore, the results showed that the majority of companies did not have a female board of commissioners at 59.7\%, because they have not implemented gender diversity policies in their supervision mechanisms. The last characteristic, the meeting conducted for one year, showed that there was intensive communication as indicated by an adequate number of meetings which were conducted by $69.7 \%$ of companies.

Table 3

Companies' Internal Control Disclosure Scores

\begin{tabular}{|c|c|c|c|c|c|}
\hline RSP & ICD & RSP & ICD & RSP & ICD \\
\hline ABMM & 0.76 & MKNT & 0.44 & SDPC & 0.28 \\
\hline GLOB & 0.72 & EMTK & 0.44 & SKYB & 0.28 \\
\hline INTA & 0.68 & KREN & 0.44 & ABBA & 0.28 \\
\hline LPPF & 0.64 & MFMI & 0.44 & MARI & 0.28 \\
\hline MPPA & 0.60 & AIMS & 0.40 & PEGE & 0.28 \\
\hline HEAL & 0.56 & FISH & 0.40 & PLAS & 0.28 \\
\hline HEXA & 0.56 & INTD & 0.40 & POOL & 0.28 \\
\hline MICE & 0.56 & OKAS & 0.40 & MIKA & 0.24 \\
\hline SPTO & 0.56 & TGKA & 0.40 & OCAP & 0.24 \\
\hline SQMI & 0.56 & TIRA & 0.40 & TRIL & 0.24 \\
\hline TURI & 0.56 & CSAP & 0.40 & MAPA & 0.24 \\
\hline RANC & 0.56 & KOIN & 0.40 & AKKU & 0.24 \\
\hline INPP & 0.56 & SONA & 0.40 & HOME & 0.24 \\
\hline MLPL & 0.56 & TELE & 0.40 & KPIG & 0.24 \\
\hline MDRN & 0.52 & BUVA & 0.40 & MABA & 0.24 \\
\hline MPMX & 0.52 & NATO & 0.40 & PDES & 0.24 \\
\hline PJAA & 0.52 & SHID & 0.40 & BLTZ & 0.24 \\
\hline LINK & 0.52 & JTPE & 0.40 & MINA & 0.20 \\
\hline BHIT & 0.52 & KBLV & 0.40 & SOTS & 0.20 \\
\hline BNBR & 0.52 & LPLI & 0.40 & DIGI & 0.20 \\
\hline ASGR & 0.48 & MLPT & 0.40 & LMAS & 0.20 \\
\hline BOGA & 0.48 & SCMA & 0.36 & SRTG & 0.20 \\
\hline UNTR & 0.48 & CARS & 0.36 & SRAJ & 0.16 \\
\hline ERAA & 0.48 & KIOS & 0.36 & RALS & 0.16 \\
\hline ECII & 0.48 & DFAM & 0.36 & ARTA & 0.16 \\
\hline NFCX & 0.48 & ICON & 0.36 & HOTL & 0.16 \\
\hline RIMO & 0.48 & JSPT & 0.36 & PUDP & 0.16 \\
\hline TRIO & 0.48 & DNET & 0.36 & MTDL & 0.16 \\
\hline JIHD & 0.48 & HKMU & 0.32 & INPS & 0.12 \\
\hline PGLI & 0.48 & MAPI & 0.32 & FAST & 0.12 \\
\hline PSKT & 0.48 & NASA & 0.32 & HRME & 0.12 \\
\hline BRMS & 0.48 & PZZA & 0.32 & MAPB & 0.12 \\
\hline DYAN & 0.48 & BMTR & 0.32 & NUSA & 0.12 \\
\hline BMSR & 0.44 & NICK & 0.32 & LUCK & 0.12 \\
\hline CLPI & 0.44 & $\mathrm{MNCN}$ & 0.28 & WICO & 0.08 \\
\hline EPMT & 0.44 & MSIN & 0.28 & ZBRA & 0.08 \\
\hline KOBX & 0.44 & SILO & 0.28 & BAYU & 0.08 \\
\hline LTLS & 0.44 & ATIC & 0.28 & CLAY & 0.08 \\
\hline DIVA & 0.44 & DWGL & 0.28 & PTSP & 0.08 \\
\hline MIDI & 0.44 & KONI & 0.28 & Average & 0.36 \\
\hline
\end{tabular}

Source: Authors' calculations.

Table 4

Descriptive of Board Characteristics

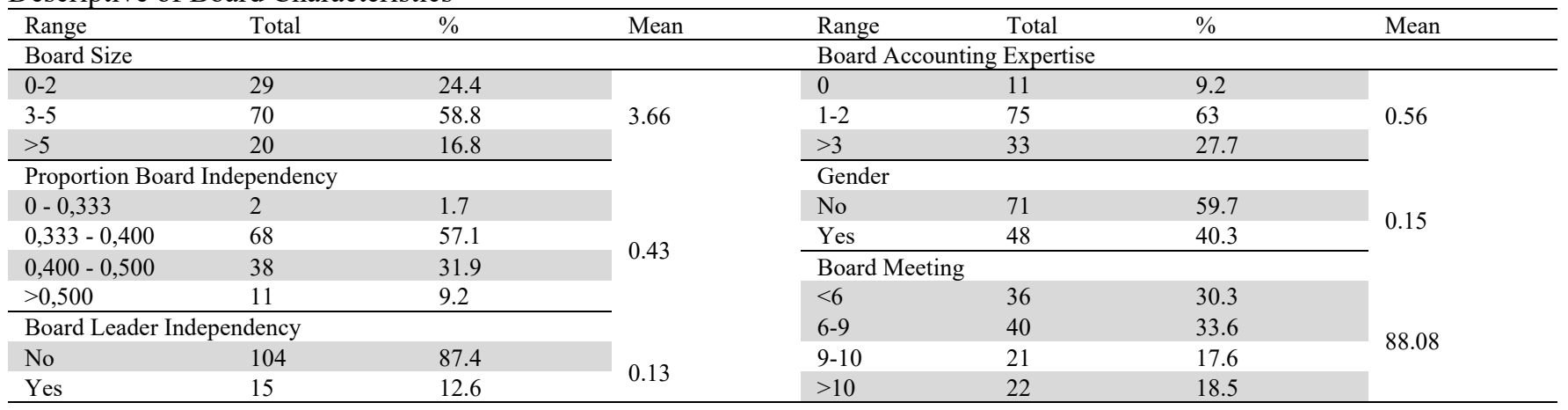

Source: Authors' calculations.

Testing for the research hypothesis was prior to obtaining a general description of the characteristics of the board of commissioners. The initial step before conducting a regression test was to calculate the classical assumptions. The testing results summarized in Table 5, showed normal distributed research data which was indicated by the Kolmogorov-Smirnov One-Sample Test value of more than 0.05 . The second test was for the occurrence of heteroscedasticity using the Spearman's rho method. 
The correlation test obtained a significance value greater than 0.05 for the relationship of each independent variable with the absolute value of the residual regression used. These results indicated no heteroscedasticity or variance inequality of residuals for all observations in the linear regression model. Meanwhile, multicollinearity testing was performed by looking at the score of the variance inflation factor (VIF) for each independent variable and the Tolerance value. The analysis results showed a VIF value of less than 10 and a Tolerance value of more than 0.01 , therefore it was concluded that there was no multicollinearity problem. The results of normality, heteroscedasticity and multicollinearity tests concluded that the data can be used for regression tests (Gujarati, 2004, p. 366). Therefore, they can all be used for hypothesis testing.

\section{Table 5}

Test of Normality, Heteroscedasticity and Multicollinearity Results

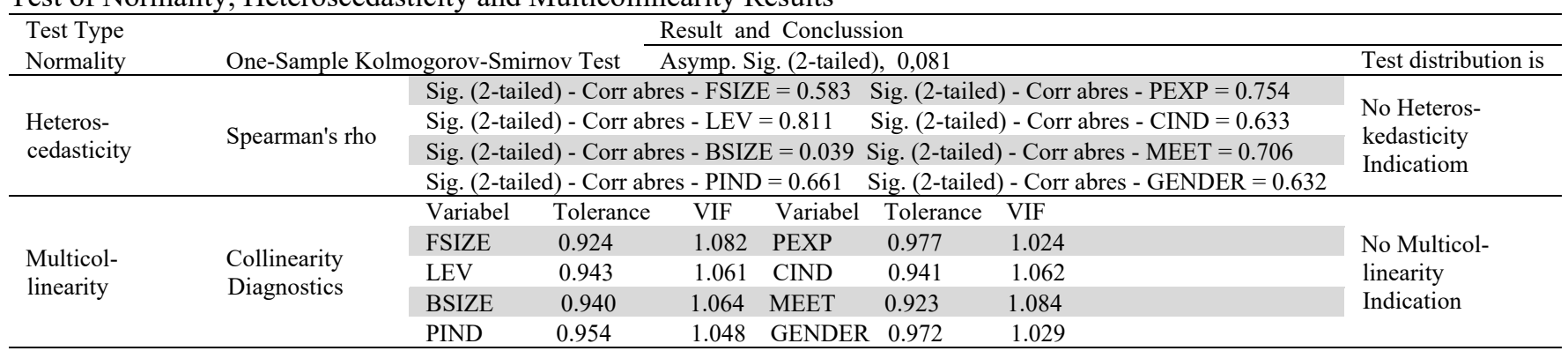

Source: Authors' calculations.

After the results of the classic assumption test showed the data can be used, the next test was a regression test between the independent and dependent variables. The results, as summarized in Table 6 , obtained an $\mathrm{R}$ Square value of $21.5 \%$, showing the explanatory power of a regression model that was sufficient for the cross-section data. Therefore, the independent variables can be used as a model to explain the extent of the internal control system disclosure, which can be seen from the $\mathrm{F}$ value and its significance. Table 6 shows that there are significant results related to the control variables FSIZE $(t=-.1,885, p=0.062(2$ tailed) and $\operatorname{LEV}(\mathrm{t}=2.941, \mathrm{p}=0.004)$. However, results of the negative coefficient, and the extent of the internal control system disclosure can affect the size of the company negatively. The results explained that the larger the size, the lower the disclosure. Meanwhile, the higher the level of corporate leverage, the higher internal control system. This result supported previous studies (Haji \& Ghazali, 2013). However, it was different from research (Allegrini \& Greco, 2013; Manita et al., 2018). This is also different from research (Agyei-Mensah, 2016) which did not have empirical support for the influence of the same control variable. The test results only support a portion of the hypotheses proposed by this study. Hypothesis, obtained empirical support as indicated by the $t$ value of 2.311 and significant at $p=0.023$. The relationship between the size of the board and the extent of the disclosure shows that the more the number of members, the higher the capacity to supervise the company's operational activities. In addition, it enables a substantial increase in knowledge related to the business environment and provides a variety of good perspectives in the decision-making process. Therefore, the more the number of supervisory boards, the wider the presentation of information obtained by the company. This result is in line with (Allegrini \& Greco, 2013; Haji \& Ghazali, 2013) that obtained a relationship between the size of the board on the extent of disclosure. However, the results (Haji \& Ghazali, 2013) obtained evidence of a relationship between them and the existence of an internal control system. This result is not in line with (Agyei-Mensah, 2016), because it does not have empirical support. Hypothesis 2 does not obtain significant results as indicated by the value of $t=0.919, p=0.360$, and Hypothesis 3 obtains the result of $t=-0.519, p=0.605$. The insignificant results show that there is no influence from the independence of the board. This result contradicts previous research (AgyeiMensah, 2016; Ahmad et al., 2015; Ashfaq \& Rui, 2019; Manita et al., 2018) that obtained a positive relationship between the independence and the extent of disclosure, and (Haji \& Ghazali, 2013) a negative relationship between the president commissioner and the extent of disclosure. However, these results support the research (Allegrini \& Greco, 2013) which concludes that the proportion of the board and the President Commissioners does not correlate with the extent of information disclosure. The absence of empirical support for these two hypotheses is supported by the descriptive results presented in Table 4 , which shows that the average number of independent commissioners is only 0.43 , meaning that there are only 2 out of a total of 5 board members. Similarly, based on their availability, only $12.6 \%$ of companies have independent commissioners. Thus, it was concluded that the condition for trading companies in Indonesia was not yet strong because the total proportion of independent commissioners with a total board member was less than $50 \%$. Therefore, it can be understood that the independence has not been proven to have an effect on improving the quality of internal control information to the public. However, most companies generally have implemented at least more than 1 independent commissioner. The analysis results provide empirical support for the fourth hypothesis which states that there is a positive influence between the accounting expertise of the board on the extent of disclosure of the company's internal control system, which is indicated by the value of $t=2,323, p=0.022$. Adequate knowledge about accounting and finance has been shown to influence the quality of the presentation of internal control system in the company's annual report. It makes the board more vigilant and attentive to important information presented to stakeholders, especially related to the practice of the internal control system. This result is in accordance with previous research 
(Ahmad et al., 2015; Felo, 2011) which concluded that the experience and literacy of accounting by the board enables better knowledge and awareness about risk and internal control systems. Therefore, it is deemed necessary to present to the public. Furthermore, adequate financial literacy will encourage companies to keep abreast of developments in a changing business environment, thus they will always follow the regulatory requirements and developments related to corporate governance.

\section{Table 6}

Regression Result

\begin{tabular}{llll}
\hline Unstandardized Coefficientsa & B & Std. Error & Sig. \\
\hline (Constant) & 0.132 & .065 & 2.019 \\
FSIZE & -0.001 & .000 & -1.885 \\
LEV & 0.015 & .046 & 2.941 \\
BSIZE & 0.018 & .062 & .004 \\
PIND & 0.093 & .008 & .023 \\
PEXP & 0.021 & .102 & .919 \\
CIND & -0.210 & .009 & 2.325 \\
MEET & 0.007 & .040 & -0.519 \\
GENDER & 0.022 & .020 & .360 \\
\hline R-Square $=0.215$ F-value=3.774 (Sig. =0.001) & & .017 & .022 \\
\end{tabular}

Hypothesis 5 which states that there is a positive influence between the gender diversity of the board of commissioners on the extent of disclosure of the company's internal control system, which obtains a result of $t=1.276, p=0.205$, thus there is no significant effect for the relationship. The findings related to the lack of support for the influence of gender diversity are in line with previous research (Ahmad et al., 2015; Manita et al., 2018) which concluded that it does not influence the level of internal control system disclosure. It is in line with the reasons stated by (Ahmad et al., 2015), that this condition in companies, especially those that are subjects of this research, is still very low. Table 4 showed a total of $59.7 \%$ of companies do not have female commissioners. Based on the mean value, most only have 1 female board of commissioners. This condition is the same as reported by the results of the study (Ahmad et al., 2015). However, it is different from the results (Ahmed et al., 2017) that obtained support for the influence of the board's gender diversity on the frequency and volume of information presented to the public. The results (Ahmed et al., 2017) indicate that the size of gender diversity is more than one female commissioners. This is also different from (Chen et al., 2016) which shows that there is an affluence in reducing reports on weaknesses of internal control. The sixth hypothesis which states that there is a positive influence between the number of the board of commissioners' meetings on the extent of disclosure of the company's internal control system is supported by the value of $t=2,876, p=0.005$. This significant result shows that the greater number of meetings conducted by the independent board, the better the disclosure of internal control system the company will obtain. The high number shows the intensity of effective supervision activities in conducting coordination with management, thereby resulting in a more transparent presentation of information. These results support previous research on the influence of the number of meetings with the quality of information disclosure (Allegrini \& Greco, 2013; Haji \& Ghazali, 2013).

\section{Conclusion}

This study has analyzed the effect of supervision activities as shown by the various characteristics of the board of commissioners. The results have shown that some characteristics of the board, such as size, accounting and financial literacy, are able to direct the company in presenting complete internal control information as required by the stakeholders. However, some of the characteristics have empirical support presented to the public. The implementation of their supervisory role causes a better working environment, thereby transparency of information to the public will be better. The absence of empirical support is in line with the conditions of practice by the company. Descriptive results show that the proportion of independence of the board of commissioners is still under 50\% and that of the President Commissioner is also very low. Meanwhile, the proportion of the existence of female boards of commissioners is very low due to lack of empirical support. By using supervision mechanisms, this study makes a theoretical contribution to the practice of information disclosure in the context of agency theory. Practical contributions are to be conveyed to the financial services authority regarding the board of commissioners and gender diversity, which has not been practiced widely. In addition, this study has limitations in measuring the extent of disclosure that is explored based on individual understanding in reading the issuer's annual financial statements and measurement items performed by combining the COSO 2013 framework with circular letter number 30 /SEOJK.04/2016. Therefore, the score or quality can only be explained based on the concepts of COSO or only implied by the circular letter of Financial Services Authority number 30 /SEOJK.04/2016. These limitations provide opportunities for further research in developing instruments in measuring the quality of information disclosure on internal control practices for companies in Indonesia.

\section{Acknowledgements}

We would like to express our utmost gratitude to the Directorate General of Research and Development of the Ministry of Research, Technology, and Higher Education for funding this research through the "Penelitian Dasar UnggulanPerguruan Tinggi” 2020 scheme. 


\section{References}

Adams, R. B., \& Ferreira, D. (2008). Women in the Boardroom and Their Impact on Governance and Performance. In Center for Economic institutions (CEI Working Paper Series, No. 2008-7 "Women). http://hdl.handle.net/10086/13885

Agyei-Mensah, B. K. (2016). Internal control information disclosure and corporate governance: evidence from an emerging market. Corporate Governance: The International Journal of Business in Society, 16(1), 79-95.

Ahmad, R. A. R., Abdullah, N., Jamel, N. E. S. M., \& Omar, N. (2015). Board characteristics and risk management and internal control disclosure level: Evidence from Malaysia. Procedia Economics and Finance, 31(2011), 601-610.

Ahmed, A., Monem, R. M., Delaney, D., \& Ng, C. (2017). Gender diversity in corporate boards and continuous disclosure: Evidence from Australia. Journal of Contemporary Accounting and Economics, 13(2), 89-107.

Allegrini, M., \& Greco, G. (2013). Corporate boards, audit committees and voluntary disclosure: Evidence from Italian Listed Companies. Journal of Management and Governance, 17(1), 187-216.

Ashbaugh-Skaife, H., Collins, D. W., Kinney, W. R., \& LaFond, R. (2008). The effect of SOX internal control deficiencies and their remediation on accrual quality. Accounting Review, 83(1), 217-250.

Ashfaq, K., \& Rui, Z. (2019). The effect of board and audit committee effectiveness on internal control disclosure under different regulatory environments in South Asia. Journal of Financial Reporting and Accounting, 17(2), 170-200.

Barros, C., Boubaker, S., \& Hamrouni, A. (2013). Corporate governance and voluntary disclosure in France. The Journal of Applied Business Research, 29(2), 561-578.

Ben-Amar, W., Chang, M., \& McIlkenny, P. (2017). Board gender diversity and corporate response to sustainability Initiatives: Evidence from the carbon disclosure project. Journal of Business Ethics, 142(2), 369-383.

Chalmers, K., Hay, D., \& Khlif, H. (2019). Internal control in accounting research: A review. Journal of Accounting Literature, $42,80-103$.

Chen, Y., Eshleman, J. D., \& Soileau, J. S. (2016). Board gender diversity and internal control Wweaknesses. Advances in Accounting, 33, $11-19$.

Cheng, M., Dhaliwal, D., Zhang, Y., Hunziker, S., Klai, N., Omri, A., Turedi, H., Celayir, D., Beest, F. Van, Boelens, S., Adnan, M. A., Rashid, H. M. A., Meera, A. K. M., Htay, S. N. N., Kasim, E., Ueda, K., De Nicoló, G., Laeven, L., Gerakos, J., ... Al-Smadi, A. A.-M. (2011). Internal control quality and investment efficiency. Journal of Accounting and Economics, 6(1), 1.

Dechow, P., Ge, W., \& Schrand, C. (2010). Understanding earnings quality: A review of the proxies, their determinants and their consequences. Journal of Accounting and Economics, 50(2-3), 344-401.

Felo, A. J. (2011). Corporate Reporting Transparency, Board Independence and Expertise, and CEO Duality. SSRN Electronic Journal.

Haji, A. A., \& Ghazali, N. A. M. (2013). A longitudinal examination of intellectual capital disclosures and corporate governance attributes in Malaysia. Asian Review of Accounting, 21(1), 27-52.

Huang, H.-W., Yan, Y.-C., Fornaro, J., \& Elshahat, A. (2011). Market reactions to audit committee director's gender: Evidence from USTraded Foreign Firms. The International Journal of Banking and Finance, 8(1), 59-75.

Li, J., Mangena, M., \& Pike, R. (2012). The effect of audit committee characteristics on intellectual capital disclosure. British Accounting Review, 44(2), 98-110.

Liao, L., Luo, L., \& Tang, Q. (2015). Gender diversity, board independence, environmental committee and greenhouse gas disclosure. British Accounting Review, 47(4), 409-424.

Manita, R., Bruna, M. G., Dang, R., \& Houanti, L. (2018). Board gender diversity and ESG disclosure: evidence from the USA. Journal of Applied Accounting Research, 19(2), 206-224.

McNally, J. S. (2013). The 2013 COSO Framework \& SOX Compliance One Approach to an Effective Transition. In The Association of Accountant and Financial Professionals in Business: Vol. June.

Michelon, G., Bozzolan, S., \& Beretta, S. (2015). Board monitoring and internal control system disclosure in different regulatory environments. Journal of Applied Accounting Research, 16(1), 138-164.

Pangaribuan, H., Donni, R. W. P., Muse, O., \& Popoola, J. (2019). Exploration Disclosures of Internal Control as the Impact of Earnings Quality and Audit Committee. 3(1), 4-22.

Sjarief, J., \& Weli, W. (2016). The internal control disclosure, the executive compensation, and the timeliness of financial reporting. International Journal of Applied Business and Economic Research, 14(2), 991-1002.

Weli, W., \& Sjarief, J. (2017). Analysis Characteristic for Internal Control Disclosure : Case Study Company Listed in Indonesian Stock Exchange. 8(2), 1-19.

Weli, W., \& Sjarief, J. (2018). The effect of internal control disclosure on financial information quality and market performance distinguished by the Corporate Governance Index. International Journal of Accounting and Financial Reporting, 8(1), 241-260.

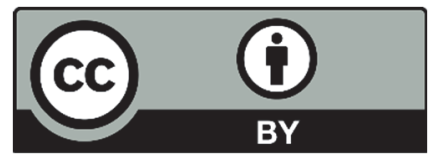

(C) 2020 by the authors; licensee Growing Science, Canada. This is an open access article distributed under the terms and conditions of the Creative Commons Attribution (CC-BY) license (http://creativecommons.org/licenses/by/4.0/). 